\title{
Foraging Behavior of Apis mellifera Linn. Visiting Some Plant Flowers in Aljabal Alakhder Region -Libya
}

\author{
Salma Y. Essa ${ }^{1}$ and Ali A. Bataw ${ }^{2}$ \\ ${ }^{1}$ Department of Zoology, Faculty of science and Art (Al guba), Omar Al-Mukhtar University \\ ${ }^{2}$ Department of Zoology, Faculty of Science-Omar Al-Mukhtar University
}

Received: 14 May 2020/ Accepted: 27 November 2020

Doi: https://doi.org/10.54172/mjsc.v35i3.258

\begin{abstract}
The study aimed to investigate the effects of nectar secretion and climate conditions on the number of honeybee workers foraging on flowers of three different plant species. Nectar samples were taken at different hours of the day. Handling and traveling time of each bee per flower were recorded. The results showed a significant difference during daylight hours on nectar volume $(\mathrm{P}>0.05)$. The highest amount of nectar was recorded at 10 am on a Prunus domestica flower plant $(0.5 \pm 0.2)$ and the lowest on a Pyrus communis flower plant at 8:00 am with $(0.0132 \pm 0.008)$. Also, the highest recorded handling time was on a Malus domestica flower plant at 10 am with $(6.1 \pm 1.7 \mathrm{Sec})$. And while there was an absence of mean handling time at 4:00 pm on the $P$. communis flower plant, The results showed that the highest traveling time recorded was on a $M$. domestica flower plant at 12 am with $(2.2 \pm 0.1 \mathrm{Sec})$ compared with the $P$. communis flower plant that recorded the lowest traveling time at 4:00 pm with $(0.1 \pm 0.1 \mathrm{Sec})$. Furthermore, the results revealed that the preference of Apis mellifera was the $M$. domestica flower plant. The findings showed a significance $(\mathrm{P}>0.05)$ between the effects of climate conditions on the number of bees during visits, while also revealing that there was a relationship between high temperatures and an increase in the number of visiting bees. Meanwhile, the number of visits decreased during the hours of observation with lower humidity.
\end{abstract}

Keywords: Apis mellifera; Flower Preference; Foraging Behavior; Handling and Traveling Times.

\section{INTRODUCTION}

It is important to collect information on the honeybee $A$. mellifera populations of Saharan and Coastal locations in Libya to fill the North Africa gap of biogeography and honey bee distribution (Shaibi, 2013). Nectar production plays a vital role in the pollination of flowering plants. Many studies have been done on nectar production and pollinator interaction, especially in tropical, southern, and southwestern American species and north European species (Beutler, 1953; Beutler \& Schöntag, 1940; Corbet et al., 1979; Huber, 1956; Loper et al., 1976; Robinson \& Oertel,
1975; Southwick et al., 1981; Wykes, 1953). Many insect species help in the process of reproduction in plants through mediating pollen from flower to flower. Pollinating insects play vital roles in agriculture (Yun, 2005). The collection of pollen and nectar from flowering plants by bees is known as foraging behavior (Gary, 1992; Michener \& Michener, 1974).

Time spent by workers flying from one flower to another on the same plant is known as traveling time (Steel et al., 1981), and time spent by a worker from entering her head in a flower to her exit as handling (Steel et al.,

*Corresponding Author: Salma Y. Essa Sy1953e@gamil.com, Department of Zoology, Faculty of science and Art (Al guba), Omar AL-Mukhtar University. 
1981). The time spent by bees on flowers depends on several factors, including the size of the flowers and the nectar found in flowers (Singh, 1979). A flowering plant, Macroptilium $s p$, a plant species located in Argentina, led to a decrease in the production of nectar, which affected the number of bee visits (Hoc et al., 2003). Many factors affect the secretion of nectar, including the age of the flower, soil content, and climatic conditions, including temperature and humidity (Savos, 1995) (Gonzalez et al., 1995).

The honeybee, A. mellifera, is flower constant, which means that on any foraging trip, it focuses on only one kind of flower. Pollen is transferred only between flowers of the same species. This is one of the features that make honey bees so popular for the commercial pollination of crops. On the downside, some scientists have expressed concern that honey bees are too efficient in their collection of nectar and pollen, leaving none in a given local flower source for the foraging of other pollinators (Buchmann \& Nabhan, 1996; Hubbell \& Braasch, 1997). Relative humidity has less effect on the flight activities of Apis species. However, a combination of temperature and humidity are important in the ripening of the anthers of flowers and the availability of pollen to visiting insects (Joshi \& Joshi, 2010). The amount of nectar decreases in plants due to high temperatures that cause its evaporation and increases its concentration which reflects in the number of visitors (Carpenter, 1983). The rate of visits by bees increases to the area of flowers by increasing the number of pen flowers (Southwick et al., 1981). This study aims to investigate the effect of nectar volume on the different activities and behavior of Apis. mellifera on three plant flowers.

\section{MATERIALS AND METHODS}

Site: The experiments were conducted in April 2015 on a farm in the Al-Abarq area, Al-Jabal AL-Alakhdar, Libya, cultivated with
Plum (Prunus domestic), Pear (Pyrus communis), and Apple (Malus domestica).

Nectar Secretion: Nectar samples $(\mu \mathrm{l} / \mathrm{f})$ were taken randomly at different hours of the day (at least ten flowers). Nectar samples were taken from 8 am to 4 pm by a capillary tube used to assure complete removal of available nectar within the flower. Nectar volume was determined by measuring the length of nectar columns in the capillary tube to the nearest $1 \mu 1$.(Dafni, 1992).

Handling and Traveling Time: Handing time for each bee per flower was recorded (by seconds), which started when visiting bees rested on a flower. Traveling times were recorded during their movement from one flower to another. All times were recorded with the help of a stopwatch. All records were taken from 8 am to 4 pm.(Pleasants, 1981).

Climate Conditions: Climate conditions were recorded by a psychomotor and a thermometer while recording the number of flowers visited by bees. Temperature and humidity recordings were taken during flower visits from 8 am to $4 \mathrm{pm}$ on observation days in an area $(1 \mathrm{~m} \times 1 \mathrm{~m})$ for each plant.

Data Analysis: All data were analyzed by Minitab program 16, by determined ANOVA, $(\mathrm{M} \pm \mathrm{SE})$, and regression analysis between different factors. Excel program was used for data graphical analysis.

\section{RESULTS}

Nectar secretion: On $P$. communis, the highest mean amount of nectar was recorded at 10:00 am. $(0.18 \pm 0.08 \mu \mathrm{l} / \mathrm{f})$ compared with the lowest mean amount of nectar which was $(0.0132 \pm 0.008 \mu \mathrm{l} / \mathrm{f})$ at 8:00 am. The highest mean amount of nectar was at 4:00 pm on $M$. domestica $(0.07 \pm 0.01 \mu \mathrm{l} / \mathrm{f})$, and the lowest mean amount of nectar was $(0.0133 \pm 0.01 \mu \mathrm{l}$ /f) at 12:00 pm. While on the flower of $P$. domestica, the highest recorded mean amount 
of nectar was $(0.5 \pm 0.2 \mu \mathrm{l} / \mathrm{f})$ at 10:00 am compared with the lowest mean amount of $\operatorname{nectar}(0.1 \pm 0.01)(\mu \mathrm{l} / \mathrm{f})$ at 2:00 pm. (Fig. 1).

The results indicated that there are significant differences $(\mathrm{P}>0.05)$ between the amount of nectar secretion during different hours of a day in all plant species (Fig.1). By comparing the three plant flowers, $P$. domestica recorded a higher mean amount of nectar $(0.2 \pm 0.05 \mu 1$ /f) while the lowest mean amount of nectar was $(0.04 \pm 0.006 \mu \mathrm{l} / \mathrm{f})$ on $M$. domestica.

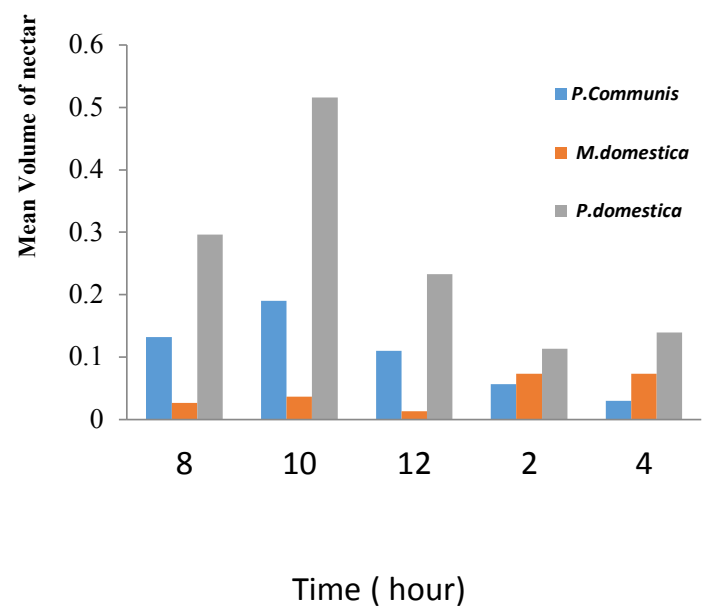

Figure 1. Mean volume $( \pm \mathrm{M})$ of nectar $(\mu \mathrm{l} / \mathrm{f})$ extracted from the three flowering plants of $P$. Communis, M. domestica, P. domestica. 50 Flower/day.

\section{Foraging activities}

\section{a. Effects of nectar secretion on $A$. mellif- era activity:}

The study recorded the numbers of $A$. mellifera on three flowers per meter square. The highest number of visits was at 10:00 am for all flowering plants respectively $(P$. Communis, M. domestica, P. domestica) (105.0, $188.0,211.0) \mathrm{f} / \mathrm{m}^{2}$. The least number of visits recorded was at 4:00 pm for all flowering plants ( $P$. communis, $M$. domestica, and $P$. domestica. $(2.00,30.0,19.0) \mathrm{f} / \mathrm{m}^{2}$ respectively (Fig. 2). The results revealed significant differences $(\mathrm{P}>0.05)$ in the number of visitors during the daytime for all plant flowers.

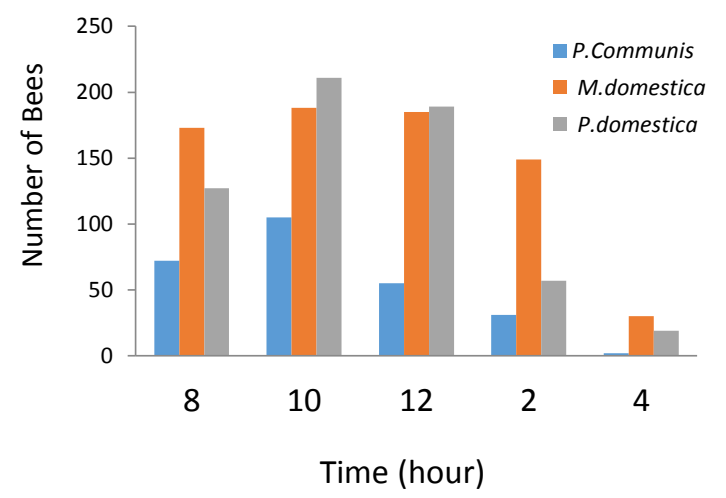

Figure2. Foraging Activity of bees A. mellifera per meter square/second, during different hours of the day between flower species.

The results showed a different preference of workers $A$. mellifera to the three plant flowers, where the highest number of bee visitors was on $M$. domestica. $P$. domestica, then the low preference was on $P$. communis. The results showed that 145 bees foraged on $M$. domestica while 120 bees on $P$. domestica and 53 on $P$. communis (Table 1).

Table (1). Preference of bees for a particular plant species.

\begin{tabular}{cl}
\hline \hline Plant Specie & Number of bees \\
\hline P. communis & $53.0^{\mathrm{b}}$ \\
M. domestica & $145.0^{\mathrm{a}}$ \\
P. domestica & $120.0^{\mathrm{a}}$
\end{tabular}

The letters in the same column are nonsignificant differences $(P<0.005)$

The results showed of a low correlation between amount of nectar secretion and worker activity on $P$. domestica $\left(R^{2}=0.4\right)$ while recorded a strong relationship on $P$. communis $\left(R^{2}=0.9\right)$ and on $M$. domestica $\left(R^{2}=0.5\right)$

\section{b. Handling and traveling time:}

The results showed significant differences $(\mathrm{P}>0.05)$ between handling and traveling times at different hours of the day. P. communis recorded the highest mean handling time at 8:00 am of $(3.7 \mathrm{Sec})$. On M. domesti$c a$, the highest mean handling time was at 10:00 am $(6.1 \mathrm{Sec})$ compared with the lowest 
mean, which was $(2.9 \mathrm{Sec})$ at 4:00 pm. While on $P$. domestica the highest mean handling time was $(3.5 \mathrm{Sec})$ at 4:00 am, compared with the lowest mean which was $(2.5 \mathrm{Sec})$ at 8:00 $\mathrm{pm}$. Also the highest mean traveling time recorded on $P$. Communis was $(2.1 \mathrm{Sec})$ at 10:00 am, compared with the lowest mean traveling time at 4:00 pm which was $(0.1$ $\mathrm{Sec})$. Also, on $M$. domestica, the highest mean traveling time was recorded at 12:00 pm (2.2 Sec) compared with the lowest mean, which was $(1.8 \mathrm{Sec})$ at 4:00 pm. While on $P$. domestica, the highest mean traveling time was $(2.0 \mathrm{Sec})$ at 2:00 am compared with the lowest mean, which was $(1.0 \mathrm{Sec})$ at $12: 00$ pm.

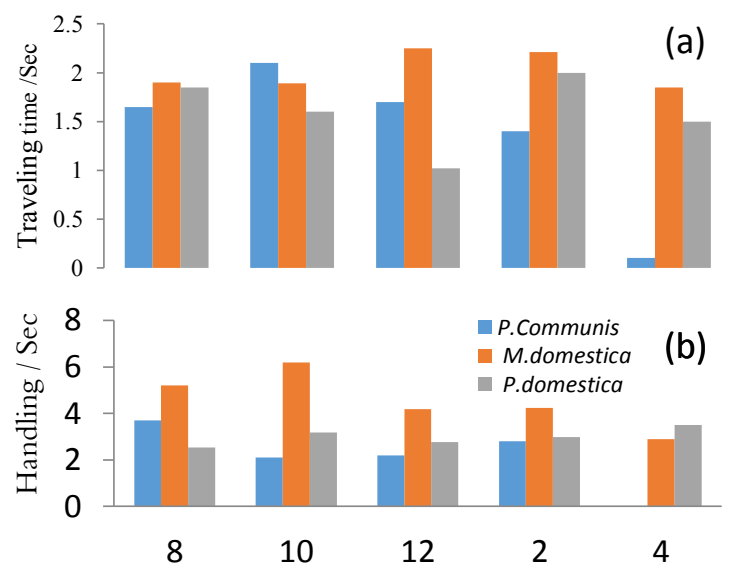

Figure 3 (a) (b). Comparison between handling time and traveling time/seconds of $A$. mellifera between the different times of the day in three flower species, 50 Flower/day.

The results showed a clear variation in handling times between the visits of bees to the three different plant flowers (one-way ANOVA), $(\mathrm{df}=2, \mathrm{~F}=13.6, \mathrm{P}>0.005)$. The highest mean handling time recorded was on $M$. domestica $(6.1 \mathrm{Sec})$ at 10:00 am compared with $P$. communis, for which at 4:00 pm, a mean handling time was not recorded. The results also showed a clear variation in traveling time with the visits of bees to the different three plant flowers (one-way ANOVA), ( $\mathrm{df}$ $=2, F=7.9, P>0.005)$. The highest mean trav- eling time was recorded at $12 \mathrm{pm}$ on $M$. domestica $(2.2 \mathrm{Sec})$. While the lowest mean traveling time was recorded on $P$. communis $(0.1 \mathrm{Sec})$ at 4:00 pm (Table 2).

Table (2). (Mean \pm SE) of handling time and traveling time of $A$. mellifera on three flower Species in $(\mathrm{Sec})$. $\mathrm{N}=$ number of flowers visited.

\begin{tabular}{lll}
\hline \hline Plant Flower & $\begin{array}{l}\text { Handling } \\
\text { Time (Sec). }\end{array}$ & $\begin{array}{l}\text { Traveling } \\
\text { Time (Sec). }\end{array}$ \\
\hline$P . \quad$ communis & $2.1 \pm 0.3 \mathrm{~b}$ & $1.3 \pm 0.1 \mathrm{~b}$ \\
$\mathrm{~N}(263)$ & & \\
M. domestic & $4.5 \pm 0.4 \mathrm{a}$ & $2.0 \pm 0.08 \mathrm{a}$ \\
$\mathrm{N}(725)$ & & \\
$P$. domestica & $2.9 \pm 0.2 \mathrm{~b}$ & $1.5 \pm 0.09 \mathrm{~b}$ \\
$\mathrm{~N}(1444)$ & & \\
\hline
\end{tabular}

The letters in same column are nonsignificant differences $(P$ $<0.005$ )

\section{a. Effects of some climate conditions on honey bee workers activity:}

The results showed effects of climate conditions on the same time of the day on flight activity. Higher rates of visitor bees were recorded in all three plants respectively $P$. communis, $M$. domestica, $p$. domestica at 10:00 am as increases in temperature continue $\left(31.1^{0} \mathrm{C}, 26,4^{\circ} \mathrm{C}\right.$, and $\left.23^{\circ} \mathrm{C}\right)$. Compared with decreases in humidly $(22.1 \%, 26.7 \%$, $33.0 \%$ ) respectively on $P$. communis, $M$. domestica, $P$. domestica at 4:00 pm, with the lower rates of visitors recorded with decreases in temperatures $\left(22.5^{\circ} \mathrm{C}, 23.7^{0} \mathrm{C}, 21.7^{0} \mathrm{C}\right)$, compared to increases in humidity $(30.0 \%$, $35.4 \%, 29.5 \%)$ respectively. The results recorded were significantly different between the temperature and the activities of the workers on the three flowering plants $(\mathrm{df}=1$ $\mathrm{f}=0.65 \mathrm{p}=0.4)$. Also, significant differences were recorded between the humidity and the activities of the workers on three flower plants $(\mathrm{df}=1 \mathrm{f}=0.18 \mathrm{p}=0.6)$.

\section{DISSCUSION}

The results revealed that the three plants showed fluctuation in nectar secretion throughout the day, and the weather conditions could potentially be the main reason. 
This was clear in particular on Apple and Pear flowers, and the results agreed with (Merti, 2003) who investigated the effect on relative humidity on nectar secretion, also results by (Corbet, 1978; Park, 1929; Shuel, 1992) the surrounding humidity effects the amount of nectar secretions.

The increase in temperatures decreases the amount of nectar available to bee visitors as it increases water evaporation in nectar (Corbet, 1990). The results on Pear recorded a different phenomenon, which could be the result of other factors that govern nectar secretion other than weather conditions. (Raw, 1953) revealed that the difference in osmosis of secretion glands and the common phenomenon in some plants' so-called habitation of nectar causes an increase in nectar secretion. These findings were presented by (Williams \& Thomson, 1998) during their study of the plant Pentstermon strictus.

The sex of flowers shows differences in the amount of nectar secretion. The female flowers of Lavandula stoechas secret double the amount of nectar secreted by male flowers (Gonzalez et al., 1995). Also, the flower's age could be a factor behind the amount of nectar secretion (Wood, 1961).

The bees' activities during the daytime show dramatic changes during their visit to the three plant flowers. The results of the current study agreed that bee activity recorded its highest rates at $10 \mathrm{am}$ and the lowest rates at $4 \mathrm{pm}$. The frequency of bee visits increases to the flower area by increasing the number of open and containerized flowers for nectar (Southwick et al., 1981). When the temperature drops, it reduces the activity of the bees, or it may be absent, as noticed by (Bataw and Lamin, 2001) on the Rosmarinus offcinalis.

The effects of the amount of nectar secreted by plant flowers during different hours of the day time show a clear difference on the time of traveling and handling in particular in Pear flowers at 8.00 am when the longest resting time was recorded where the amount of nectar is low. The same conclusion was reported by (Bataw and Lamin, 2001) during their investigation of the foraging behavior of Apis mellifera on the nectar of Rosmarinus officialis. While the amount of nectar at $2.00 \mathrm{pm}$. was high, the bees became absent, which could be due to the reduction in the nectar concentration. In apple flowers, the resting time was higher at $10 \mathrm{am}$ with high amounts of nectar.

The preference for honey bees to forage in apple flowers, could be due to the fact that apple blossoms are more attractive to bees than pear blossoms as a result of the sugar content. This agrees with other researches which mentioned the important of sugar concentration (Schneider et al., 2004; Schneider et al., 2002; Vansell, 1946). The honey bees showed less preference to the flowers of $p$. communis due to the low amount of nectar within the flower and the low concentration of sugar (Mayer, 1993; Mayer \& Lunden, 1996; McGregor, 1976; Willmer, 2011) also pointed out the importance of the location of flowers in the branches of trees, which determines the presence and activity of many insect pollinators.

The climatic conditions have a visible effect on the visitors' activity on the flowers. The current study showed a significant difference in the number of bee visitors during the day hours and the relationship between temperatures and relative humidity during the study. The highest rates of visits in all plants were recorded during average high temperatures and low relative humidity. Similar results were recorded of the visitors' activity on the flowers, influenced by factors such as temperatures, relative humidity, rain, and wind (Thorp \& RW, 1979). Little flight activity occurs at or below $10^{\circ} \mathrm{C}(50 \mathrm{~F})$, while the number of bees taking trips increases as the temperature continues to rise above $\left(20^{\circ} \mathrm{C}\right)$ (Joshi \& Joshi, 2010). 


\section{REFERENCES}

Bataw, A. A. \& I. B. Lamin (2001). The behavior of honey bees Apis mellifera L. that visit Rosemary flowers Rosmarinus officinalis L. in Al-Gabal Alakhder region. AL-Mukhtar Journal of Sciences, 8: 26-41.

Beutler, R. (1953). Nectar. Bee World, 34(6), 106-116.

Beutler, R., \& Schöntag, A. (1940). Über die Nektarabscheidung einiger Nutzpflanzen. Zeitschrift für vergleichende Physiologie, 28(3), 254285.

Buchmann, S. L., \& Nabhan, G. P. (1996). The forgotten pollinators. Island Press.

Carpenter, F. (1983). Pollination energetics in avian communities: simple concepts and complex realities. Handbook of experimental pollination biology. Van Nostrand Reinhold, New York, 215-234.

Corbet, S. A. (1978). Bee visits and the nectar of Echium vulgare L. and Sinapis alba L. Ecological Entomology, 3(1), 25-37.

Corbet, S. A. (1990). Pollination and the weather. Israel Journal of Plant Sciences, 39(1-2), 13-30.

Corbet, S. A., Willmer, P., Beament, J., Unwin, D., \& Prŷs - Jones, O. (1979). Post secretory determinants of sugar concentration in nectar. Plant, Cell \& Environment, 2(4), 293-308.

Dafni, A. (1992). Pollination ecology: a practical approach. Oxford University Press.

Gary, N. E. (1992). Activities and behavior of honeybees. The hive and the honey bee.
Gonzalez, A., Rowe, C., Weeks, P., Whittle, D., Gilbert, F., \& Barnard, C. (1995). Flower choice by honey bees (Apis mellifera L.): sex-phase of flowers and preferences among nectar and pollen foragers. Oecologia, 101(2), 258-264.

Hoc, P., Drewes, S., \& Amela, G. M. (2003). Floral biology, reproductive system and reproductive success of Macroptilium fraternum (Fabaceae). Revista de biologia tropical, 51(2), 369.

Hubbell, S., \& Braasch, G. (1997). Trouble with Honeybees. Natural history, 106(4), 32-43.

Huber, H. (1956). Die Abhängigkeit der Nektarsekretion von Temperatur, Luftund Bodenfeuchtigkeit. Planta, 48(1), 47-98.

Joshi, N. C., \& Joshi, P. (2010). Foraging behaviour of Apis spp. on apple flowers in a subtropical environment. New York Science Journal, 3(3), 71-76.

Loper, G., GD, W., \& RL, B. (1976). Effect Of Flower Age On Sucrose Content In Nectar Citrus.

Mayer, D. (1993). Sequential introduction of honey bee colonies for pear pollination. VI International Symposium on Pear Growing 367,

Mayer, D., \& Lunden, J. (1996). A comparison of commercially managed bumblebees and honey bees (Hymenoptera: Apidae) for pollination of pears. VII International Symposium on Pollination 437 ,

McGregor, S. E. (1976). Insect pollination of cultivated crop plants (Vol. 496). Agricultural Research Service, US Department of Agriculture. 
Merti, A. A. (2003). Botanical Inventory and Phenology in Relation to Foraging Behaviour of the Cape Honeybees (Apis Mellifera Capensis) at a Site in the Eastern Cape, South Africa Rhodes University Grahamstown].

Michener, C. D., \& Michener, C. D. (1974). The social behavior of the bees: a comparative study. Harvard University Press.

Park, O. (1929). The influence of humidity upon sugar concentration in the nectar of various plants. Journal of Economic Entomology, 22(3), 534-544.

Pleasants, J. M. (1981). Bumblebee response to variation in nectar availability. Ecology, 62(6), 1648-1661.

Raw, G. (1953). The effect on nectar secretion of removing nectar from flowers. Bee World, 34(2), 23-25.

Robinson, F., \& Oertel, E. (1975). Sources of nectar and pollen. The hive and the honey bee, 283-303.

Schneider, D., Eisikowitch, D., Goldway, M., \& Stern, R. (2004). A comparative study of the superior fertility of 'Smoothee Golden Delicious' apple. The Journal of Horticultural Science and Biotechnology, 79(4), 596-601.

Schneider, D., Stern, R. A., Eisikowitch, D., \& Goldway, M. (2002). The relationship between floral structure and honeybee pollination eficiency in 'Jonathan'and 'Topred'apple cultivars. The Journal of Horticultural Science and Biotechnology, 77(1), 48-51.

Shaibi, T. (2013). The honeybees (Apis mellifera L) of Libya. Egyptian Academic Journal of Biological Sciences. A, Entomology, 6(2), 39-47.
Shuel, R. (1992). The production of nectar and pollen. The hive and the honey bee, 401-436.

Singh, Y. (1979). Pollination activity on strawberry at Jeolikote (district Nainital, India). Indian Bee J.

Southwick, E. E., Loper, G. M., \& Sadwick, S. E. (1981). Nectar production, composition, energetics and pollinator attractiveness in spring flowers of western New York. American Journal of Botany, 68(7), 994-1002.

Steel, R. G.and J. H. Torrie. (1980).Principles and Procedures of Statistics. A Biometrical Approach, New York. McGraw-Hill.inc p .593

Thorp, R., \& RW, T. (1979). Honey bee foraging behavior in California almond orchards.

Vansell, G. (1946). Bees and pear pollination. Oregon State Hort. Soc. Proc. 37, 5153.

Williams, N. M., \& Thomson, J. D. (1998). Trapline foraging by bumble bees: III. Temporal patterns of visitation and foraging success at single plants. Behavioral Ecology, 9(6), 612-621.

Willmer, P. (2011). Pollination and floral ecology. Princeton University Press.

Wood, G. (1961). The association between age of inflorescence and nectar production in the low-bush blueberry Vaccinium angustifolium. Canadian Journal of Botany, 39(5), 1037-1040.

Wykes, G. (1953). The sugar content of nectars. Biochemical Journal, 53(2), 294-296.

Yun, H. (2005). Insects-mediated pollination. Korean Soc. Insect Resour. Res, 5, 1. 


\title{
سلوك البحث عن الغذاء لنحل العسل .Apis mellifera Linn خلال زيارة بعض النباتات الزهرية في منطقة الجبل الأخضر، ليبيا
}

\author{
سالمة ياسين عيسى 1" وعلي عبد القادر بطاو2 2

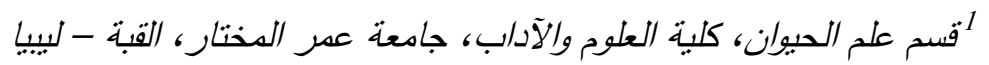

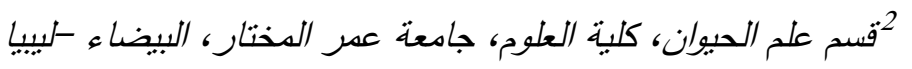

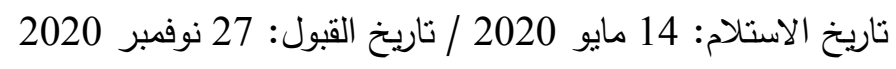
https://doi.org/10.54172/mjsc.v35i3.258 :Doi

المستخلص: يهدف البحث إلى دراسة آثار إفراز الرحيق والظروف المناخية على عدد شغالات نحل عسل الباحثة عن الغذاء في أزهار ثلاثة أنواع نباتية مختلفة، تم أخذ عينات الرحيق في أوقات مختلفة من ساعات النهار، وتم تسجيل الوقت الذي تستغرقه

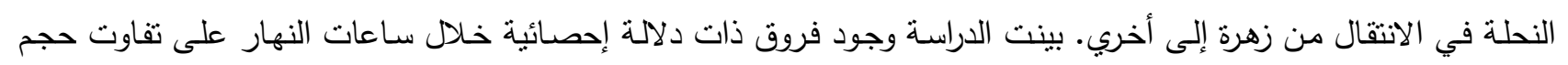

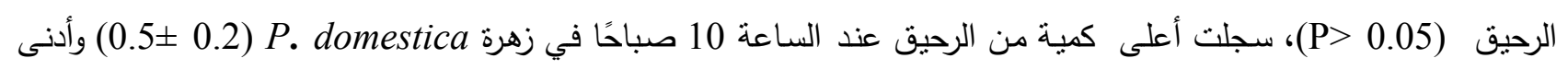

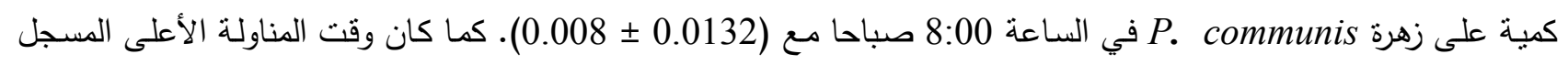

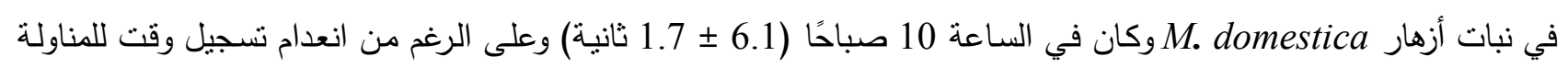

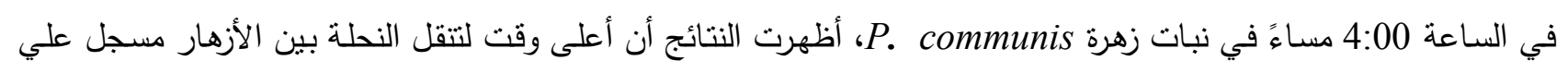

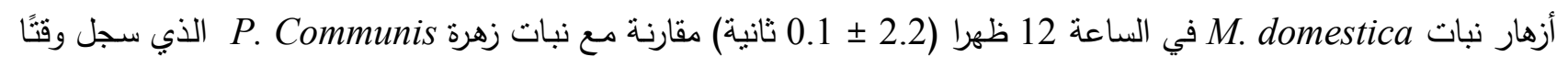

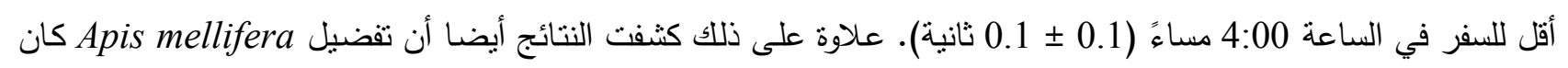

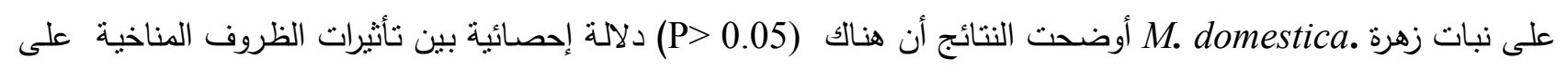
عدد النحل أثناء الزيارة، بينما أظهرت وجود علاقة بين ارتفاع درجة الحرارة وزيادة عدد النحل الزائرين، بينما انخفض عدد الزئة الزيائرات خلال ساعات الدراسة مع انخفاض نسبة الرطوبة. الكلمات المفتاحية: Apis mellifera، تفضيل الزهرة، سلوك البحث عن الغذاء، زمن المناولة والتتل. 